Сања Цвркота

Библиотека града Београда
УДК 050:271.222(497.11)

дОИ https://doi.org/10.18485/

melissa.2016.15.1.ch14

\title{
ПЕРИОДИКА СРПСКЕ ПРАВОСЛАВНЕ ЦРКВЕ НА ИНТЕРНЕТУ
}

\begin{abstract}
Сажетак
Крајем деведесетих година прошлог века у Српској православној цркви се озбиљно посветила пажња осмишљавању могућности коришћења интернет технологије у циљу мисије цркве и повезивања и комуникације верских заједница. Издаваштво црквене периодике већ одавно се преселило и на интернет. У раду је сачињен преглед и аналаиза периодике Српске православне цркве која је данас присутна на Интернету. Бројни часописи, гласници, билтени и листови похрањени су у пдф формату на сајтовима институција Српске православне цркве.
\end{abstract}

Кључне речи: црквена периодика, Српска православна црква, интернет, црквени сајтови

Црква је приметила значај присуства у виртуелном свету, а прва међународна конференција о дигиталним медијима и православној пастирској бризи, одржана је у периоду од 7-9 маја 2015. године у Атини. Прву конференцију те врсте у свету организовале су интернет странице Пемптусија из Грчке, OCN - Orthodox Christian Network из Америке и Bogoslov.ru из Русије. Учествовало је 75 предавача из 21 земље, који су представљали све помесне Православне Цркве. На конференцији је истакнуто да мисионарење преко интернета представља велики изазов, јер излазак у сајбер простор захтева одговарајућу припрему и посебне услове. На конференцији су истакнуте негативне стране попут злоупотребе, као и прекомерне употребе интернета. Наглашене су и опасности које прете човеку као личности, као и однос верника према Богу и Цркви у новој стварности коју креирају нове технологије. Међутим, многи учесници су нагласили изазов за мисионарење који произилази из нових друштвених услова, које обликују савремене технологије. Један од учесника 
ове конференције и онај који је међу првима закорачио из редова Српске православне цркве у сајбер простор био је игуман манастира Лепавина отац Гаврило Вучковић. Он је у свет информатике ушао по благослову свог надлежног владике митрополита Јована Павловића, који је саветовао да манастир Лепавина навбави компјутер. И тако је све почелпо од издавања духовних листића и манастирског часописа, преко сајта, покренута је виртуелна духовна трибина а потом и директна комуникација путем Скајпа. И у осталим епархија Српске православне цркве примећена је неопходност употребе погодности које пружају савремене информационе технологије. Једна од тих погодности је свакако и презентовање периодике преко интернета.

У овом раду предмет истраживања је управо периодика чија је грађа присутна на интернету, тј. у пдф формату. До закључних резултата се дошло на основу претрраге сајтова епархија Српске православне цркве, интернет периписке са уредничким одборима појединих наслова периодике и личним контактима.

Периодика Српске православне цркве, коју је могуће наћи на интернету, можемо систематизовати према митрополијама и епархијама Српске православне цркве у којима се публикује, а у оквиру ове систематизације такође можемо сачинити садржајну категоризацију периодике (информативна, верско-образовна и научно-богословска).

Табеларно приказано претходно наведена систематизација изгледа овако:

\begin{tabular}{|c|c|}
\hline $\begin{array}{c}\text { митрополије и епархије Српске } \\
\text { православне цркве }\end{array}$ & $\begin{array}{c}\text { садржајна категоризација } \\
\text { периодике и број наслова }\end{array}$ \\
\hline Архиепископија београдско карловачка & $\begin{array}{c}\text { информативна (6) } \\
\text { верско-образовна (3) } \\
\text { научно-богословска (1) }\end{array}$ \\
\hline Аустралијско-новозеландска митрополија & $\begin{array}{c}\text { информативна (1) } \\
\text { верско-образовна (1) }\end{array}$ \\
\hline Дабробосанска митрополија & верско-образовна (1) \\
\hline Загребачко-љубљанска митрополија & верско-образовна (1) \\
\hline Црногорско-приморска митрополија & верско-образовна (1) \\
\hline Бихаћко-петровачка епархија & верско-образовна (1) \\
\hline
\end{tabular}


ВИРТУЕЛНА КУЛТУРА

\begin{tabular}{|c|c|}
\hline Браничевска епархија & научно-богословска (1) \\
\hline Британско-скандинавска епархија & информативна (1) \\
\hline Будимљанско-никшићка епархија & верско-образовна (1) \\
\hline Горњокарловачка епархија & информативна (1) \\
\hline Далматинска епархија & верско-образовна (2) \\
\hline Жичка епархија & $\begin{array}{c}\text { информативна (1), верско-образовна } \\
\text { (2) }\end{array}$ \\
\hline Захумско-херцеговачка & научно-бословска (1) \\
\hline Западноевропска епархија & информативна (2) \\
\hline Зворничко-тузланска епархија & $\begin{array}{c}\text { информативна (1), верско-образовна } \\
\text { (1) }\end{array}$ \\
\hline Канадска епархија & $\begin{array}{c}\text { информативна (2), верско-образовна } \\
\text { (2) }\end{array}$ \\
\hline Крушевачка епархија & верско-образовна (2) \\
\hline Нишка епархија & верско-образовна (1) \\
\hline $\begin{array}{c}\text { Новограчаничко- } \\
\text { средњезападноамеричка епархија }\end{array}$ & информативна (4) \\
\hline Осјечкопољска и барањска епарија & верско-образовна (1) \\
\hline Сремска епархија & информативна (1) \\
\hline Франкфуртска епархија и све Немачке & информативна (3) \\
\hline Шумадијска епархија & верско-образовна (1) \\
\hline Охридска архиепископија & $\begin{array}{c}\text { информативна (1), верско-образовна } \\
\text { (1) }\end{array}$ \\
\hline
\end{tabular}

Данас Српска православна црква има укупно 40 мањих целина (митрополије и епархије), од чега из горње табеле видимо да њих 25 ради на томе да своју православну мисију и делатност прошири и путем интернет приступа њиховим серијским публикацијама. Процентуално гледајући, то је 62, 5 \% што заслужује сваку похвалу.

\section{1. Периодика информативног садржаја}

Периодика информативног садржаја је, заправо, периодика која доноси обавештења о текућим дешавањима у Српској православној цркви, те тако представља основни информатор верницима и свештенству. Ова периодика садржи и пригодне чланке за вернике, с 
обзиром на црквене празнике, који се у датом моменту прослављају, а и обавештење о ставу свештенства Српске православне цркве према текућим догађањима у земљи и свету.

Табеларни приказ периодике информативног садржаја:

\begin{tabular}{|c|c|}
\hline \multicolumn{2}{|c|}{ БЕОГРАДСКО-КАРЛОВАЧКА АРХИЕПИСКОПИЈА } \\
\hline $\begin{array}{l}\text { БИЛТЕН Храма Свете Тројице } \\
\text { у Сремчици }\end{array}$ & http://www.crkvasvetetrojice.rs/ \\
\hline $\begin{array}{c}\text { ГЛАСНИК Цркве св. Димитрија } \\
\text { на Новом Београду }\end{array}$ & $\begin{array}{l}\text { http://www.hramsvetogdimitrija.rs/parohijski- } \\
\text { glasnik/ }\end{array}$ \\
\hline $\begin{array}{c}\text { ЕВАНЂЕЛИСТ : парохијски лист } \\
\text { Цркве Светог Марка, Београд } \\
\text { ISSN 2217-5512 }\end{array}$ & http://www.crkvasvetogmarka.rs/ \\
\hline $\begin{array}{c}\text { НЕДЕЉНИ ГЛАСНИК Цркве } \\
\text { Светог СИмеона Мироточивог } \\
\text { на Новом Београду }\end{array}$ & http://sveti-simeon.com/ \\
\hline $\begin{array}{c}\text { САБОРНИК : билтен } \\
\text { београдске Саборне иркве } \\
\text { храма Светог } \\
\text { Архангела Михаила, Београд }\end{array}$ & http://www.saborna-crkva.com/ \\
\hline $\begin{array}{c}\text { СлОВО : билтен раковачке } \\
\text { цркве, Београд }\end{array}$ & http://www.crkvarakovica.rs/bilten/ \\
\hline
\end{tabular}

\begin{tabular}{|c|c|}
\hline \multicolumn{2}{|c|}{ АУСТРАЛИЈСКО-НОВОЗЕЛАНДСКА МИТРОПОЛИЈА } \\
\hline ПАРОХИЈСКИ ЛИСТ Црквене & http://www.svetikrali.org.nz/sr/parohijski-list \\
општине Свети краљь Милутин & \\
Српски за Окланд и Хамилтон, & \\
Нови Зеланд & \\
\hline
\end{tabular}

\section{БРИТАНСКО-СКАНДИНАВСКА ЕПАРХИЈА}

ПАРОХИЈСКО ПИСМО : лист којИ http://spclondon.org/vesti/parohijsko-pismo издаје Српска Православна црквена општина и парохија Светог Саве у Лондону 


\section{ГОРЊОКАРЛОВАЧКА ЕПАРХИЈА}

СВЕТИ САВА ГОРЊОКАРЛОВАЧКИ : $\quad$ http://www.eparhija-gornjokarlovacka.hr/ гласник Епархије горњокарловачке

ISSN 1334-3467

\section{ЖИЧКА ЕПАРХИЈА}

ХРАM : билтен парохије при Храму http://eparhija-zicka.rs/list-hram/ Светог Саве у Краљеву

\section{ЗАПАДНО-ЕВРОПСКА ЕПАРХИЈА}

ГЛАС : парохијски лист Храма Светог Саве у Бриселу http://www.svetisava.be/parohija/34

ПАРОХИЈСКИ ГЛАСНИК, Црква св. Цара Константина и царице Јелене у Луксембургу

http://www.spclux.lu/sr/parohijskiglasnik.html

\section{ЗВОРНИЧКО-ТУЗЛАНСКА ЕПАРХИЈА}

ПАРОХИЈСКО ПИСМО, Црква св. Николе http://svetinikola.org/parohijsko-pismo/ у Милошевцу

\section{КАНАДСКА ЕПАРХИЈА}

ГЛАСНИК, Црква Св. Саве у Ванкуверу ISSN 1708-0584 glasnik.html

ПАРОХИЈСКИ ГЛАСНИК, Црква св.

Симеона Мироточивог, Калгари http://svetisimeon.org/serb/?page $\underline{\mathrm{id}=168}$

\section{НОВОГРАЧАНИЧКО-СРЕДЊОЗАПАДНОАМЕРИЧКА ЕПАРХИЈА}

БИЛТЕН ЦРКВЕ СВ. НИКОЛЕ = SТ. NICHOLAS BULLETIN, Индијанополис bulletins/

БИЛТЕН ЦРКВЕ СВЕТЕ ТРОЈИЦЕ, СенТ Луис

http://www.serbianchurchstlouis.org/ churchbulletins.html

ГЛАС РАВАНИЦЕ, Црква св. Кнеза http://ravanica.org/church/glas/ Лазара, Детроит

СПАСОВДАН, Српска православна https://crkvarockford.wordpress.com/ мисионарска парохија Вазнесења Господњег, Рокфорд 


\section{CРЕМСКА ЕПАРХИЈА}

ПАРОХИЈСКИ ВЕСНИК : лист Цркве Рођења Пресвете Богородице у Батајници ISSN 2217-2882

\begin{tabular}{|c|l|}
\hline \multicolumn{2}{|c|}{ ФРАНКФУРТСКА ЕПАРХИЈА И СВЕ НЕМАЧКЕ } \\
\hline $\begin{array}{c}\text { ПАРОХИЈСКО ПИСМО, парохија за } \\
\text { централни Шварцвалд у Филинген- } \\
\text { Швенингену }\end{array}$ & http://www.spc-schwarzwald.eu/ \\
\hline $\begin{array}{c}\text { ПАРОХИЈСКО ПИСМО, Српска православна } \\
\text { црква у Оснобрику }\end{array}$ & $\underline{\text { http://www.spc-osnabrueck.de/ }}$ \\
\hline $\begin{array}{c}\text { ПАРОХИЈСКО ПИСМО Српске православне } \\
\text { парохије у Дортмунду }\end{array}$ & $\underline{\text { http://www.srpska-crkva-dortmund.de/ }}$ \\
\hline
\end{tabular}

\begin{tabular}{|l|l|}
\hline \multicolumn{3}{|c|}{ ОХРИДСКА АРХИЕПИСКОПИЈА } \\
\hline$Ц$ ЦРКВА & http://www.poa-info.org/izdavastvo/crkva \\
\hline
\end{tabular}

Сви наведени билтени и гласници су углавном парохијски, и то њих 22 наслова а остала два наслова су епархијска (Свети Сава Горњокарловачки : гласник Епархије горњокарловачке и Црква, Охридске архиепископије). Сва грађа је доступна на интернету од следећих наслова:

- Глас Раванице, Црква св. Кнеза Лазара, Детроит

- Гласник, Црква Св. Саве у Ванкуверу

- Гласник иркве св. Димитрија на Новом Београду

- Недељни гласник иркве Светог Симеона Мироточивог на Новом Београду

- Парохијски гласник, Цркве св. Симеона Мироточивог, Калгари

- Храм : билтен парохије при Храму Светог Саве у Краљеву

А што се тиче додељених ISSN бројева, тиме се могу похвалити уредништва следећих наслова:

- Гласник, билтен Цркве Св. Саве у Ванкуверу (ISSN1708-0584)

- Еванђелист : парохијски лист Цркве Светог Марка у Београду (ISSN 2217-5512)

- Парохијски весник : лист Цркве Рођења Пресвете Богородице у Батајници (ISSN 2217-2882)

- Свети Сава Горњокарловачки (ISSN 1334-3467) 


\section{2. Периодика верско-образовног садржаја}

Периодика верско-образовногсадржајаподразумевапериодику која служи православној веронауци српског народа. Саобразно томе којој читалачкој публици је била посвећена подељена је на периодику за одрасле, за децу и омладину и за монаштво. Наиме, у све три ове категорије читалачке публике осећа се потреба за бољом православном просветом. Путем ове периодике одрасли су даровани надахнутом речју српског православног свештенства о основним догматима праволсавне вере, деци се прилази кроз песму, причу и слику, а монаштво светоотачком мудрошћу крепи себе и оне који су кренули светоотачким путем.

Следипрегледпрема већутврђенојсистематизацијипропраћено кратким описима побројаних серијских публикација, будући да је ова врста периодике особито популарна у Српској православнох цркви.

\begin{tabular}{|c|l|}
\hline \multicolumn{2}{|c|}{ БЕОГРАДСКО-КАРЛОВАЧКА АРХИЕПИСКОПИЈА } \\
\hline МАЛИ МИСИОНАР, Манастир свети \\
Стефан Сланци & $\frac{\text { http://www.manastirsvetistefan.org/o- }}{\text { manastiru/mali-misionar }}$ \\
\hline РАСТКО : лист за православну српску & http://www.bogoslovijasvetogsave.edu.rs/ \\
омладину, а од 2015 поднаслог гласи \\
часопис Богословије Св. Саве намењен \\
омладини \\
ISSN 2406-2634
\end{tabular}

Богословија Светог Саве у Београду чији почеци датирају још од богословије коју је установио Доситеј Обрадовић 1810. године у издаваштву периодике има лист Растко. Намењен је српској омладини, тако што јој приближава духовне и културне вредности нашег народа. Излазио је од 1996. до 1999. године и наставио опет да излази од 2015. године.

Светосавско звонце је у својих скоро 45 година постојања, прешло пут од подлистка новина српске патријаршије Православље, до најтиражнијег часописа Српске православне цркве. Свој пут ка 
деци током свих ових деценија, стрпљиво је градило васпитавајући и учећи многе генерације о нашој вери, историји и традицији.

Растко и Светосавско звонце су заступљени и у електронском каталогу НБС. Сва грађа Растка је доступна на нету.

\begin{tabular}{|c|l|}
\hline \multicolumn{2}{|c|}{ АУТРАЛИЈСКО-НОВОЗЕЛАНДСКА МИТРОПОЛИЈА } \\
\hline $\begin{array}{c}\text { СВЕТОСАВСКО СЛОВО, Парохија } \\
\text { св. краља Милутина за Окланд и } \\
\text { Хамилтон, Нови Зеланд }\end{array}$ & $\underline{\text { slovo }}$ \\
\hline
\end{tabular}

Светосавско слово излази четири пута годишње (Божић, Васкрс, Видовдан и Крстовдан). Садржи вести из парохије, богословље, беседе, народне обичаје, интервјуе и страницу за децу.

\begin{tabular}{|c|c|}
\hline \multicolumn{2}{|c|}{ ДАБРОБОСАНСКА МИТРОПОЛИЈА } \\
\hline $\begin{array}{c}\text { ДАБАР : билтен манастира Успења } \\
\text { Пресвете Богородице у Добруну }\end{array}$ & $\begin{array}{l}\text { http://www.mitropolijadabrobosanska.org/ } \\
\text { dabararhiva.html }\end{array}$ \\
\hline
\end{tabular}

Дабар, лист Српске православне парохије сарајевске, који је већ после првог броја постао часопис Митрополије дабробосанске, излазио је двомесечно у Сарајеву, од 1985. године. Престао је са излажењем 1992. услед грађанског рата и наставио поново са излажењем 1996. године. Садржи вести из митрополије, беседе, житија светих, духовне поуке.

\begin{tabular}{|c|l|}
\hline \multicolumn{2}{|c|}{ ЗАГРЕБАЧКО-ЉУБљАНСКА МИТРОПОЛИЈА } \\
\hline $\begin{array}{c}\text { ПУТ, ИСТИНА И ЖИВОТ } \\
\text { ISSN 1331-2405 }\end{array}$ & $\begin{array}{l}\text { http://www. manastir-lepavina.org/ } \\
\text { stranica.php?id=17 }\end{array}$ \\
\hline
\end{tabular}

Пут, истина и живот је часопис манастира Лепавина. Излазио је од 1997. до 2005. године и то у шест бројева годишње, а понеки број је био двоброј. Садржи углавном текстове познатих теолога намењених пре свега монаштву, а, наравно, и свим православним верницима. Сва грађа је доступна на нету и има га и у елкетронском каталогу НБС. 


\begin{tabular}{|c|c|}
\hline \multicolumn{2}{|c|}{ ЦРНГОРСКО-ПРИМОРСКА МИтРОпОлИЈА } \\
\hline $\begin{array}{c}\text { СВЕТИГОРА : образник за вјеру, } \\
\text { културу и васпитање } \\
\text { ISSN 0354-3366 }\end{array}$ & http://www.mitropolija.com/svetigora/ \\
\hline
\end{tabular}

Светигора је часопис Митрополије црногорско-приморске који излази од 1991. године. Садржи црквене беседе, репортаже, поезију, предавања, духовне поуке, хронику митрополије. Прати пре свега дешавања у Митрополији црногорско-приморској али и у СПЦ и свим другим помесним православним црквама. Веома има запажено место у периодици СПЦ, што квалитетом издања, као и квалитетом текстова, а и својим континуитетом.

\begin{tabular}{|c|l|}
\hline \multicolumn{2}{|c|}{ БИХАЋКО-ПЕТРОВАЧКА ЕПАРХИЈА } \\
\hline $\begin{array}{c}\text { ЕПАРХИЈСКИ БЛАГОВЈЕСНИК : часопис } \\
\text { Епархије бихаћко-петровачке }\end{array}$ & https://sites.google.com/site/ \\
\hline
\end{tabular}

Епархијски благовјесник Епархије бихаћко-петровачке. Излази четри пута годишње. Има богословске текстове, црквено-историјске и библијске. На сајту су доступни неколицина текстова из ранијих бројева.

\begin{tabular}{|c|l|}
\hline \multicolumn{2}{|c|}{ БУдимљАНСКо-никшићкА ЕПАРХИЈА } \\
\hline $\begin{array}{c}\text { СВЕВИЂЕ : лист епархије Будимљанско- } \\
\text { Никшићке за вјеронауку, хришћанску } \\
\text { културу и живот цркве } \\
\text { ISSN 1800-5209 }\end{array}$ & svevidje/16/svevidje-102.pdf \\
\hline
\end{tabular}

Свевиђе излази од 2002. године двомесечно. Ради се на томе да се на сајт епархије похрани цела архива претходних бројева. Засад има неколицина последњих бројева.

\begin{tabular}{|c|c|}
\hline \multicolumn{2}{|c|}{ ДАЛМАТИНСКА ЕПАРХИЈА } \\
\hline $\begin{array}{c}\text { ИСТИНА : лист Српске православне } \\
\text { епархије далматинске } \\
\text { ISSN 1451-2181 }\end{array}$ & $\begin{array}{l}\text { http://www.eparhija-dalmatinska.hr/ } \\
\text { Frames-c.htm }\end{array}$ \\
\hline $\begin{array}{c}\text { KPKA : часопис Епархије Далматинске } \\
\text { ISSN 1334-4293 }\end{array}$ & $\begin{array}{l}\text { http://www.eparhija-dalmatinska.hr/ } \\
\text { Frames-c.htm }\end{array}$ \\
\hline
\end{tabular}


У оквиру Истине - издавачке куће Епархије Далматинске, поред богословског магазина Истина која излази од 2000. године од 2003. године излази и друго гласило - Крка. Речју и сликом сведочи о животу и подвигу Српске православне цркве и народа у Епархији Далматинској.

\begin{tabular}{|c|c|}
\hline \multicolumn{2}{|c|}{ ЖИЧКА ЕПАРХИЈА } \\
\hline $\begin{array}{c}\text { ЖИЧКИ БЛАГОВЕСНИК : часопис } \\
\text { Жичке епархије }\end{array}$ & http://eparhija-zicka.rs/arhiva-blagovesnik/ \\
ISBN 978-86-84933-33-3 ? & \\
\hline $\begin{array}{c}\text { ПРАВОСЛАВНИ СВЕТИОНИК } \\
\text { ISSN 1451-3730 }\end{array}$ & http://eparhija-zicka.rs/arhiva-svetionik/ \\
\hline
\end{tabular}

Засад имају само пет бројева Жичког баговесника у пдф формату у архиви часописа на сајту епархије. Жички благовесник не излази већ неко време, планиран је поновни излазак крајем 2016. године.

Часопис Православни светионик је покренуло Братство Светог Владике Николаја при храму Рођења Пресвете Богородице у Косјерићу крајем 2002. године, а са жељом да се прикупе и на једном месту објаве поучни текстови различите тематике (повезаност Бога и науке, брак и породица, поуке духовника, православље и савремено доба, православље у свету и сведочанства о чудима Божијим), који би могли бити корисни и интересантни парохијанима поменуте Богородичине цркве. Буџет је обезбеђен од добровољних прилога парохијана.

\begin{tabular}{|c|l|}
\hline \multicolumn{2}{|c|}{ ЗВОРНИЧко-тУзЛАНСКА ЕПАРХИЈА } \\
\hline $\begin{array}{c}\text { ЖИВОТВОРНИ ИСТОчНИК : часопис } \\
\text { Епархије зворничко-тузланске } \\
\text { ISSN 2303-8411 }\end{array}$ & http://www.eparhijazvornickotuzlanska. \\
\hline
\end{tabular}

Животворни источник је часопис Епархије зворничко-тузланске који је покренут 2014. године. Првенствени циљ је допринос утврђивању духовног и националног бића народа Епархије зворничко-тузланске. Сва грађа је на нету. 


\begin{tabular}{|c|c|}
\hline \multicolumn{2}{|c|}{ КАНАДСКА ЕПАРХИЈА } \\
\hline ИСТОЧНИК = Istočnik : гласник СПЦ \\
Епархије канадске \\
ISSN 0845-5392
\end{tabular}

Источник излази тромесечно од 1987. године. Обично је доступан на интернету само последњи број.

\begin{tabular}{|c|c|}
\hline \multicolumn{2}{|c|}{ КРУШЕВАЧКА ЕПАРХИЈА } \\
\hline $\begin{array}{c}\text { БОГОМЛАДЕНАЦ : часопис за децу } \\
\text { Православне Епархије крушевачке } \\
\text { ISSN 2334-9875 }\end{array}$ & $\begin{array}{l}\text { http://www.eparhijakrusevacka.com/ } \\
\text { kontakt/casopis/ }\end{array}$ \\
\hline $\begin{array}{c}\text { ПРАВОСЛАВНА ВЕРА И ЖИВОТ } \\
\text { ISSN 1452-1873 }\end{array}$ & $\begin{array}{l}\text { http://www.eparhijakrusevacka.com/ } \\
\text { kontakt/casopis/ }\end{array}$ \\
\hline
\end{tabular}

Православна вера и живот је часопис Епархије крушевачке излази од 2012. године као наследник истоименог листа архијерејског намесништва крушевачког, а затим цркве Лазарице. Садржи богословске текстове, духовен поуке у циљу мисије православља.

Богомладенац је часопис за младе епархије крушевчке и изчази од 2014. г.

Оба часописа налазе се у пдф формату на сајту епархије.

\begin{tabular}{|c|c|}
\hline \multicolumn{2}{|c|}{ НИШКА ЕПАРХИЈА } \\
\hline САГЛАСЈЕ : часопис Епархије нишке & http://eparhijaniska.rs/ \\
за хришћанску просвету и културу : & \\
[православни илустровани часопис] & \\
\hline
\end{tabular}

Године 2014. почео је са излажењем часопис Сагласје, богат илустрацијама и квалитетним духовним текстовима, али само део грађе је на нету.

\begin{tabular}{|c|c|}
\hline \multicolumn{2}{|c|}{ ОСЈЕЧКО-ПОљСКА И БАРАњСКА ЕПАРХИЈА } \\
\hline $\begin{array}{c}\text { ПРЕОБРАЖЕЊЕ : верско-поучни и } \\
\text { информативни часопис Српске православне } \\
\text { Епархије осечко-пољске и барањске са } \\
\text { седиштем у Даљу } \\
\text { ISSN } 1334-8884\end{array}$ \\
\hline
\end{tabular}


Сва грађа часописа Преображење је на нету.

\begin{tabular}{|c|c|}
\hline \multicolumn{2}{|c|}{ ШУМАДИЈСКА ЕПАРХИЈА } \\
\hline $\begin{array}{c}\text { КАЛЕНИЋ } \\
\text { ISSN 1820-6166 }\end{array}$ & http://www.eparhija-sumadijska.org.rs/ \\
\hline
\end{tabular}

Каленић излази годишње од 1997. године а двомесечно од 1994. године. Сва грађа је на интернету.

\begin{tabular}{|l|l|}
\hline \multicolumn{2}{|c|}{ ОХРИДСКА АРХИЕПИСКОПИЈА } \\
\hline САБОРНОСТ & $\begin{array}{l}\text { http://www.poa-info.org/izdavastvo/ } \\
\text { sobornost }\end{array}$ \\
\hline
\end{tabular}

Дакле, сва грађа је доступна од следећих наслова:

- Богомладенац : часопис за децу Православне Епархије крушевачке

- Животворни источник : часопис Епархије зворничко-тузланске

- Каленић

- Православна вера и живот

- Пут, истина и живот

- Растко

- Саборност : часопист Епархије Браничевске

A ISSN бројеви додељени су следећим насловима:

- Богомладенац ISSN 2334-9875

- Животворни источник ISSN 2303-8411

- Истина ISSN 1451-2181

- Источник ISSN 0845-5392

- Каленић ISSN 1820-6166

- Крка ISSN 1334-4293

- Православна вера и живот ISSN 1452-1873

- Православни светионик ISSN 1451-3730

- Преображење ISSN 1334-8884

- Пут, истина и живот ISSN 1331-2405

- Растко ISSN 2406-2634 
- Свевиђе ISSN 1800-5209

- Cветигора ISSN 0354-3366

- Светосавско звонце ISSN 1451-7191

Има укупно 21 наслов периодике верско-образовног садржаја који су делимично или у потпуности доступни на интернету. Од тога 14 наслова има и свој ISSN број.

Може да се примети да нарочито код информативне периодике а и код великог броја верско-образовне периодике није придаван значај сарадњи са нациналним ISSN центром Србије.

\section{Научно-богословска периодика}

Научно-богословска периодика је огледало научног рада интелктуалне елите у Српској православној цркви. Научно-богословску периодику углавном су покретали професори богословских факултета, или остала православна интелектуална елита, тежећи да се својим радовима прикључе решавању сваремених богословских, а и општедруштвених проблема. Ова периодика обилује и преводима савремених интелктуалаца из осталих православнихпомеснихцркава, као и радовима неправославних интелектуалаца (англиканаца, протестаната, римокатолика).

\begin{tabular}{|c|c|}
\hline \multicolumn{2}{|c|}{ БЕОГРАДСКО-КАРЛОВАЧКА АРХИЕПИСКОПИЈА } \\
\hline $\begin{array}{l}\text { БОГОСЛОВЉЕ } \\
\text { ISSN 0006-5714 }\end{array}$ & http://bogoslovlje.pbf.rs/index.php/arhiva \\
\hline
\end{tabular}

Часопис Богословље, часопис Православног богословског факултета у Београду, доступан је на сајту и има архиву издања од 2005. године. Садржински покрива све богословске науке и у часопису поред радова професора Православног богословског факултета у Београду, публикују се и радови осталих професора домаћих и страних универзитета, као и оних научника чији предмет проучавања залази у богословске науке. 


\begin{tabular}{|c|c|}
\hline \multicolumn{2}{|c|}{ БРАНИЧЕВСКА ЕПАРХИЈА } \\
\hline $\begin{array}{c}\text { САБОРНОСТ } \\
\text { ISSN 1450-9148 }\end{array}$ & $\begin{array}{l}\text { h t tp: / / casopis.sabornost.org / } \\
\text { sveska?serija=2\&id sveska }=34\end{array}$ \\
\hline
\end{tabular}

Саборност је часопис Одбора за просвету и културу при Епархији пожаревачко-браничевској. Поред тога што су доступни хронолошки сви чланци претходних бројева часописа у пдф, чланци су и алфабетски разврстани по ауторима. Саборност се појавио као наставак старијег прекинутог Браничевског весника (1941), а има задатак да допринесе очувању истинске православне вере Цркве као и њене правилне презентације свету, у данашњем времену крупних историјских превирања, али не само за живот нашег народа и уопште за све православне народе, већ и света у целини. Категоризован је као научни часопис и од стране Министарства просвете, науке и технолошког развоја Републике Србије 2013. године.

\begin{tabular}{|c|l|}
\hline \multicolumn{2}{|c|}{ ЗАХУМСКО-ХЕРЦЕГОВАЧКА ЕПАРХИЈА } \\
\hline $\begin{array}{c}\text { ВИДОСЛОВ : саборник Епархије } \\
\text { захумско-херцеговачке и приморске } \\
\text { ISSN 1840-149X }\end{array}$ & http://eparhija-zahumskohercegovacka. \\
com/?page_id=91 \\
\hline
\end{tabular}

Видослов излази три пута годишње, о Божићу, Васкрсу и Преображењу, и од почетка излажења до данас није изостало објављивање ниједног броја. У првим бројевима су прегалаштвом епископа Атанасија Јевтића објављивани драгоцјени преводи светоотачких текстова и савременог богословља, а била су праћена и актуелна збивања у тада страдалној Херцеговачкој епархији. Данас је то часопис са сарадницима у Епархији Захумско-херцеговачкој и прморској, Богословском факултетима у Београду и Србињу и студентима постдипломцима и докторантима у неколико европских земаља, који се труде да Видослову понуде најбоље текстове из области теологије, философије и умјетности, а и даље се у часопису прате збивања у Епархији. Сваки број је тематски илустрован дјелима црквене и лијепе свјетовне умјетности. На сајту епархије у архиви часописа налазе се у пдф формату тренутно сви бројеви од 34 до 60, и то само насловне странице бројева, као и одабрани радови у целости. 
Било би добро када би научно-богословска периодика била присутнија на интернету, али вероватно ће се ускоро порадити и на томе. Сматрам да је у свему томе неопходна сарадња и са надлежним библиотекама, како би се кроз заједничке пројекте дошло до неопходних средстава.

\section{Закључак}

Живимо у времену брзих (сажетих и кратких) информација, тако да и медији за пренос информација, попут штампаних медија (књиге, часописи, новине, листови, билтени, каталози итд.) добијају нову форму. Траженији штампани медији постају доступни читалачкој публици и у дигиталној верзији на сајтовима издавачких кућа или сајтовима институција у чијем окриљу постоји издавачка продукција, као и на сајтовима самих библиотека, архива, института, музеја и осталих институција које баштине писану реч. Периодика је већ одавно један од водећих медија за праћење информација, мада имамо и модерније медије данашњице, али они нису тема овог рада.

Ако погледамо данас присутност периодике Српске православне цркве у издавштву можемо да констатујемо да су свеприсутни, како у штампаној, тако и у дигиталној верзији. Свакако то је последица све активнијег црквеног живота, враћања веронауке у школе, слободе вероисповести, уважавања ставова верских поглавара о дешавањима у друштву, такође изношења ставова професора богословских школа и факултета о текућим актуелним темама и из верског и из световног живота, као и све више порастом интерсовања читалачке публике за духовне садржаје.

Свакако да и издаваштво црквене периодике има своје успоне и падове манифествоване кроз поврмене недостатке редовног буџета, али већином је базирано на огромном ентузијазму и посвећености уређивачких и редакцијских тимова бројних већ широко познатих и препознатљивих наслова. 


\section{Литература и извори}

Сања Шкондрић, Библиографија часописа Богословље : магистарски рад, Београд, 2006 http://www.spc.rs/sr/linkovi/linkovi_eparhija

http://www.manastir-lepavina.org/video_lep/pdf/Pravoslavni_misionar_oGavrilo_ konferencija_u_Grckoj.pdf

\section{Sanja Curkota}

\section{PERIODICALS OF THE SERBIAN ORTHODOX CHURCH ON THE INTERNET}

\section{Summary}

At the end of the nineties of the XX century the Serbian Orthodox Church seriously devoted attention to making the possibilities of using internet technology to the mission of the church and communication in religious communities. Publishing church periodicals have long moved on the internet. It is made a review and analysis periodicals of the Serbian Orthodox Church, which is now present on the internet. Many magazins, gazettes, bulletins and newspapers are stored in pdf format on the websites of institutions of the Serbian Orthodox Church.

Key words: church periodicals, the Serbian Orthodox Church, internet, church websites 